\title{
Deterministic Optimization Method (DOM) of Permanent Magnet Flux Switching Machine (PMFSM) for Application of Electric Bikes
}

\author{
Laili Iwani Jusoh ${ }^{1}$, Erwan Sulaiman ${ }^{1}$, Hassan Ali Soomro ${ }^{1}$, S.M.N.S. Othman ${ }^{1}$, M. Firdaus. MH ${ }^{2}$ \\ Research Center for Applied Electromagnetics, University of Tun Hussein Onn Malaysia, Locked Bag 101, \\ Parit Raja, Batu Pahat, Johor, Malaysia ${ }^{1}$, Centre for Robotics \& Industrial Automation, Fakulti Kejuruteraan \\ Elektrik Universiti Teknikal Malaysia Melaka (UTeM), Durian Tunggal, Melaka² \\ lailiiwani@gmail.com, erwan@uthm.edu.my, engg.hassansoomro@gmail.com,s.m.naufal@gmail.com, \\ mohd.firdaus@utem.edu.my
}

\begin{abstract}
Over the past decades, For various applications, permanent magnet flux switching machines (PMFSM) have attracted revived research interests. The machines not only obtain most merits from the conventional permanent magnet synchronous machines but also have a simple passive and hence robust rotor. The research paper presents a single-phase PMFSM analysis of initial and optimize design for electric bike applications. The 2D-FEA analysis was used to certify the result analysis of these motors. As a result, the design of optimized is significantly lesser magnet volume and high torque compare to the initial motor PMFSM design by using the "deterministic optimization method" (DOM). The optimized motor design has greater average torque performance analysis up to $16 \%$ whereas the permanent magnet weight decreased by $28 \%$. As a result, the machine becomes an efficient lightweight motor for electric vehicles and low cost because of a reduction in PM weight.
\end{abstract}

Key words: Flux-switching machine, initial, single-tooth, permanent magnet, optimization, deterministic optimization method.

\section{INTRODUCTION}

As the number of motor vehicles on the world's roads grows astonishingly every year, dependency on oil-based fuel increases almost uncontrollably [1]. The increased use of non-renewable fossil fuels entails environmental issues such as the "greenhouse effect," health complications for urban supplies, and uncertainty about the sustainability of the supply of fuel. [2], [3]. Many countries are also considering banning such vehicles, and many European cities, including the United Kingdom, China, France, Germany, India, Ireland, Israel, and Norway, have aims to ban combustion vehicles (petrol and diesel) by 2040 [4].
Another approach to reducing environmental pollution is by using electric vehicles (EVs) [5]-[9]. Among EVs, electric bicycles (e-bikes) are receiving more attention worldwide due to their many benefits [10]. With developing technologies, the worldwide sales of e-bicycles are predicted to grow from nearly 32 million units in 2014 to over 40 million units in 2023 [11]. As reported by Research of Navigant[12], China is expected to be the largest market of electric bikes in the world. As shown in Figure 1, referring to the sale of about 30 million units from 2016 to 2025, China is the highest compare to the other country in the world.

Nevertheless, Electric bikes are exposed to the country's guidelines and regulations [38]. The design of an electric bike for a bike-sharing system involves the consideration of two key points of concern. First, the operator needs to concentrate on a reliable, simple, effective, sustainable yet profitable system. [39]. A recent study found that cost and regular motor fault were among the key barriers to the use of e-bikes, whereas low costs, light weight, longevity, and smart features were among the key incentives to use them. [40].

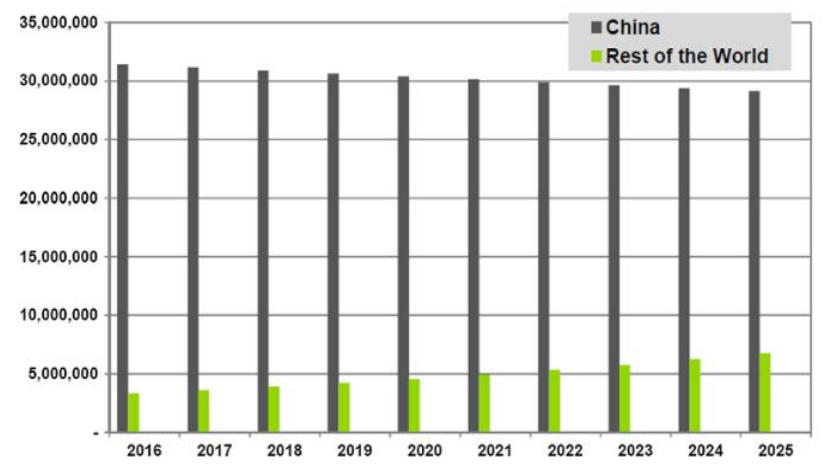

Figure 1: Annually Market Sale for Electric Bike in China and other countries in the world.

However, in order to overcome the road load including of the aerodynamic drag, the rolling resistance, the tractive force 
against the gravitational pull when climbing up a slope and the tractive force for acceleration, the motor must provide sufficient torque [41]. Motor for electric bikes is acceptable to have a $250 \mathrm{~W}$ at maximum power rating and a $25 \mathrm{~km} / \mathrm{hr}$ maximum speed (wheel speed of $200 \mathrm{rpm}$ ) for safety reasons [42]. Moreover, the basic requirement highlighted for electric motors used in electric bikes would be the potential of providing higher torque per motor volume development [43]. Due to space limitations, the electric motor use in an electric bike requires a short axial length and lightweight [44]. Consequently, the material selection must be a focus on economical that require low-cost material, including for production equipment and tooling, hence, the cost of processing be able to reduce.

The study and reduction of the permanent magnet (PM) has been devoted to numerous studies. The characteristics and sensitivity analysis of design parameters influence the output torque [14]-[16]. This paper presents the design and optimization of an SRM., to maximize the average torque with modify the motor geometry for optimal parameters while trying to minimize the size of the permanent magnet in the motor. The purpose of this optimization was both to achieve the best possible performance of a 4-slot-8-pole PMFSM and to understand the most relevant performance-enhancing parameters. This optimization focused on the optimum number of turns as well as on the optimum shape of winding slots by keeping the winding slot area approximately constant.

The current study focuses on the comparative performance of the initial and optimization of PMFSM design for electric bike applications. Primarily, the designs are examined under no-load conditions, followed by the load analysis to determine the performance of power and torque of the motor design.

\section{STRUCTURE DESIGN OF PMFSM}

The primary machine geometrical dimension is identical in Figure 2. It displays the enlarged motor with the original size of the main machine parts including for example in the space between the rotor and stator, the rotor length and armature coil, and stator yoke diameter.

\subsection{Design Specifications and Restriction}

This model, from a practical point of view, the stator diameter for the motors has been fixed at $85 \mathrm{~mm}$. The requirements and characteristics of the design of PMFSM are presented in Table I. The cross-section of the multi-tooth, single-tooth and segmental-tooth design has been shown in Fig. 2. Eventually, the design was formed by using simulation software, JMAG Designer version 14.3.

Design specifications for dimensions of the motors and the workflow for 2D analysis are illustrated in Figure 3. The design specification and conditions for all the design motors should be similar. The project implementation has been divided into two-phase which are the design and analyze the performance of PMFSM respectively. Geometry editor is applied to design all the motor parts separately for example in the rotor, stator, and armature coil whereas the simulation and set of conditions of the motor formed by utilizing the JMAG-Designer.

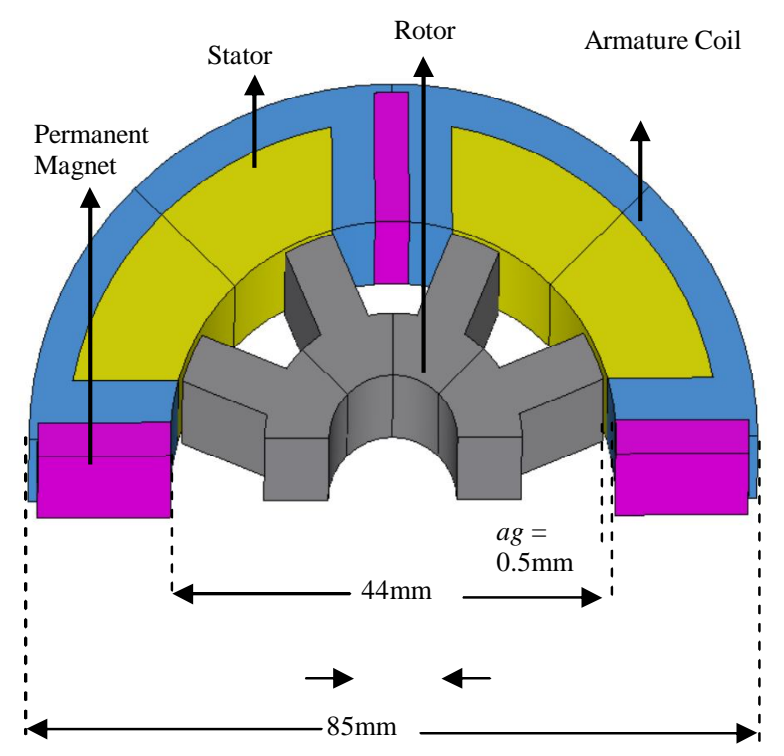

Figure 2: Main Machine Dimension of the Proposed PMFSM

Table 1: PMFSM for Electric Bike Design Requirement

\begin{tabular}{|c|c|}
\hline Items & Parameter \\
\hline Number of rotors & 8 \\
\hline Number of stators & 4 \\
\hline No. of phase & 1 \\
\hline Diameter (mm) & 85 \\
\hline inner stator radius (mm) & 26.0 \\
\hline stator outer radius (mm) & 42.5 \\
\hline rotor outer Radius (mm) & 25.5 \\
\hline Rotor width (mm) & 10.5 \\
\hline Rotor shaft (mm) & 7.5 \\
\hline Motor stack length (mm) & 30 \\
\hline Air gap length (mm) & 0.5 \\
\hline
\end{tabular}




\subsection{Possible Combinations of PMFSM Design Parameter Sensitivity}

To achieve the highest performance design, the best possible combination of the number of poles needs to be set [21]. Therefore, some relevant parameters are considered for the potential combination development of stator and rotor poles [20]. This slot and poles combination can be identified using (1) and (2).

$$
\begin{aligned}
& N_{s}=K_{m}(K=2,4,6 \ldots) \\
& \left.N_{r}=N_{a}(2 n-1)+1\right)
\end{aligned}
$$
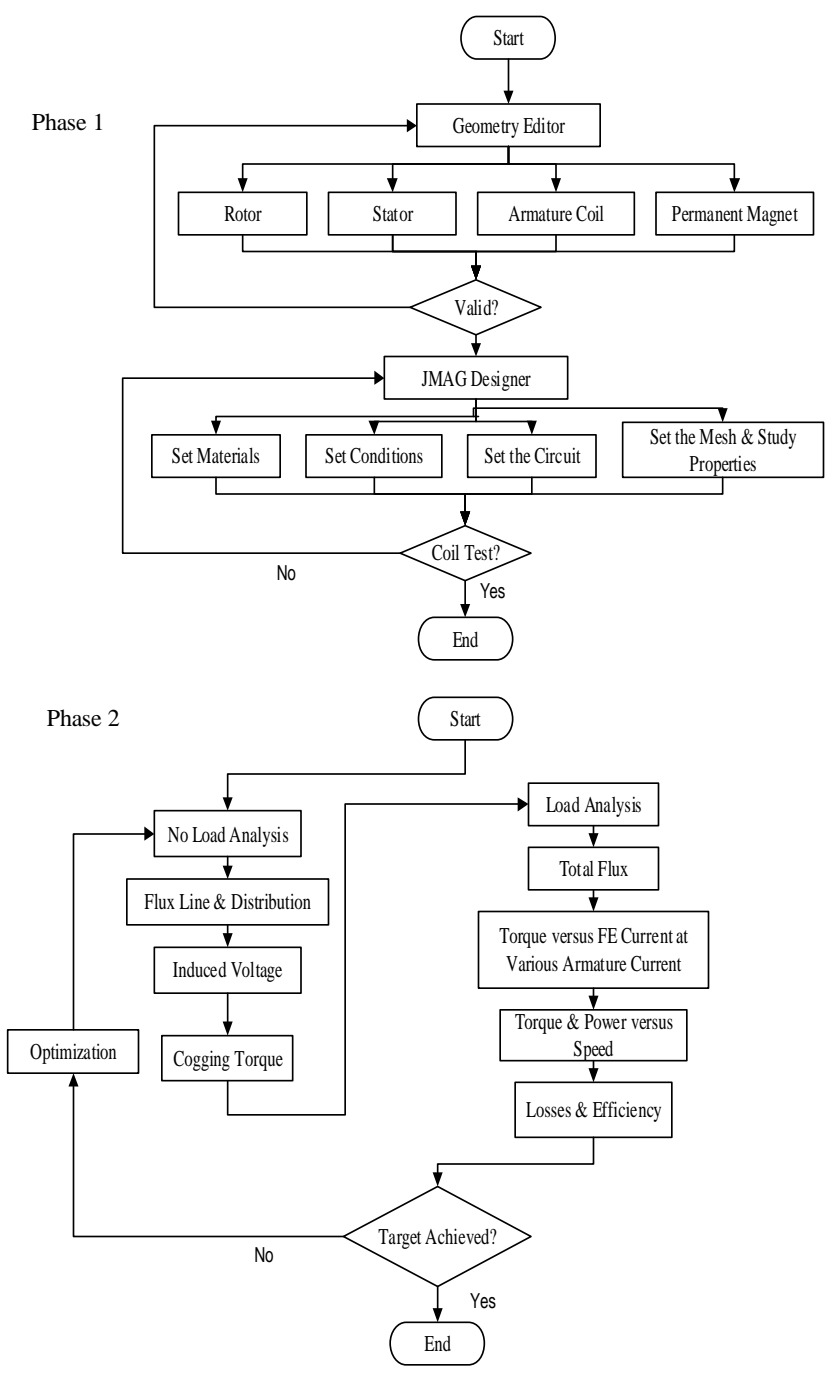

Figure 3: Analyze Performance Based on JMAG Designer with 2D FEA Analysis

The subscripts $N s$ and $N r$ will be the number of stator and rotor poles, respectively, while the number of phases is $m$. More generally, the number of rotor pole and slot pole especially for single-phase must be in even numbers.
Therefore, the PMFSM motor can be designed as a phase winding comprises a coil that has a phase shift of 180 electrical degrees among the coils.

Preliminary, according to the design of single-tooth PMFSM, the total of stator slots area must be even numbers. Accordingly, referring to equation (3), the correlation between the stator slot and rotor pole number is $N_{s}$ and $N_{r}$ respectively [6].

$$
N_{m}=N_{s}\left(1 \pm^{k / 2 q}\right)
$$

Therefore, the symbol of $(k)$ and $q$ is a natural entity with its value of 1,2 , and 3 and by the number of phases respectively. Furthermore, the electric frequency $(f e)$, of a proposed motor can be designated as (4).

$$
\mathrm{f}_{\mathrm{e}}=\mathrm{Nr}_{\mathrm{m}} \rightarrow \mathrm{f}_{\mathrm{m}}
$$

Consequently, $f e$ and $f m$ is the electric frequency and mechanical rotation frequency. The current of the armature coil $\left(I_{a}\right)$ and the number of turns $\left(N_{a}\right)$ are determined through the (5) and (6), separately whereas considering the diameter specification used for the copper is $0.56 \mathrm{~mm}$.

$$
\begin{aligned}
& I_{a}=\sqrt{N_{r}, \propto, S_{a}} / N_{a} \\
& N_{a}-\infty . S_{n} /\left(u\left(\frac{A_{\text {eangar }}}{2}\right)^{2}\right.
\end{aligned}
$$

Subscripts ' $a$ ' indicates armature coil, $J_{a}, S_{a}$, and $A_{\text {copper }}$ are current density, slot area $\left(\mathrm{mm}^{2}\right)$, and area of copper, respectively. Through the analysis, $240 \mathrm{~V}$ DC bus voltage is the appropriate electrical limit for the inverter and 3.5 Arms $/ \mathrm{mm}^{2}$ for the maximum current of the inverter, while Ja $10 \mathrm{Arms} / \mathrm{mm}^{2}$ are set to correspond to the current density in the armature coil. Since the design is focused to compare the analysis of the motor, some of the parameters remain constant. The motor stack length is set to $30 \mathrm{~mm}$ and the air gap is $0.5 \mathrm{~mm}$. To ensure the flux flows uniformly without any leakage from the stator to the rotor, the motor's filling factor $(\alpha)$ is set to 0.5 . The power is found using equation (7), and that is proportional to the torque and speed analysis.

$$
P=2 \pi / 60(\pi: 5)
$$




\section{PERFORMANCE ANALYSIS OF PMFSM OPTIMIZATION DESIGN}

The motor of 4slot-8pole PMFSM is compared among the initial and optimize the design for electric bike application and presented in Table 2. The design analysis for comparison of the initial and final design is conducted under no load and $\mathrm{n}$ load analysis. The load analysis examination contains the analysis of flux linkage, cogging torque, and back electromagnetic force (back-EMF), nevertheless, at load analysis, output power and torque performance will be analyzed completely at various armature current densities (Ja).

Table 2: Initial and Optimization Key Design Criterion

\begin{tabular}{|c|c|c|}
\hline Items & Initial & Optimize \\
\hline Number of rotors & 8 & 8 \\
\hline Number of stators & 4 & 4 \\
\hline No. of phase & 1 & 1 \\
\hline Number of turns & 438 & 459 \\
\hline $\begin{array}{c}\text { Armature slot area } \\
\text { (mm }{ }^{2}\end{array}$ & 201.6 & 216.8 \\
\hline Diameter (mm) & 85 & 85 \\
\hline $\begin{array}{c}\text { Stator inner } \\
\text { radius(mm) }\end{array}$ & 26.0 & 27.0 \\
\hline $\begin{array}{c}\text { Stator outer } \\
\text { radius(mm) }\end{array}$ & 42.5 & 42.5 \\
\hline $\begin{array}{c}\text { Rotor outer } \\
\text { radius(mm) }\end{array}$ & 25.5 & 26.5 \\
\hline $\begin{array}{c}\text { Rotor inner } \\
\text { radius(mm) }\end{array}$ & 7.5 & 7.5 \\
\hline Rotor pole height & 10.5 & 9.5 \\
\hline $\begin{array}{c}\text { Rotor pole width } \\
\text { (mm) }\end{array}$ & 6.0 & 7.0 \\
\hline PM width (mm) & 5.0 & 4.0 \\
\hline PM length (mm) & 15.5 & 15.5 \\
\hline $\begin{array}{c}\text { Stator back length } \\
\text { (mm) }\end{array}$ & 4.5 & 4.0 \\
\hline $\begin{array}{c}\text { Rotor yoke length } \\
\text { (mm) }\end{array}$ & 7.5 & 9.5 \\
\hline Air gap length (mm) & 0.5 & -5 \\
\hline Stator bridge(mm) & 1.0 & $70 \mathrm{~g}$ \\
\hline PM Volume (g) & (m) \\
\hline
\end{tabular}

\subsection{Characteristics of Magnetic Flux Linkage}

The magnetic flux for both designs of initial and optimize in PMFSM is produced by magnetic flux linkage (induce voltage) and achieved by rotation of rotor at the speed of 500 $\mathrm{r} / \mathrm{min}$ whereas the current density for armature is fixed at 0 Arms $/ \mathrm{mm}^{2}$. As can be seen in Figure 4, The magnitude rose to $0.5 \mathrm{~Wb}$ compare to the initial design at $0.4 \mathrm{~Wb}$. The flux is increased due to the diminished size of the rotor pole height. Therefore, the flux magnetic may take for a short period to perform one complete cycle and minimized the flux leakage, and flux cancellation has been decreased which also influences by the magnitude of flux linkage.

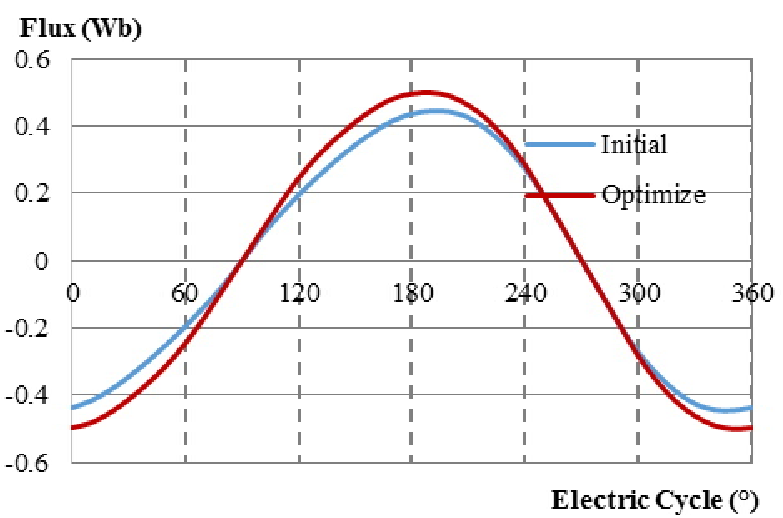

Figure 4: Initial and optimize flux linkage performance comparison

\subsection{Electromagnetic Force (Back-EMF)}

An additional analysis of the initial and optimised PMFSM back-electromagnetic force (EMF) topology at an open circuit is performed at a speed of $500 \mathrm{r} / \mathrm{min}$. The achieved results of back-EMF are plotted in Figure 5. The voltages generated by optimized design are greater compare to the initial design since back-EMF is directly related to the magnetic flux linkage. Since the magnitude of magnetic flux is increased so back-EMF is also enlarged. Moreover, higher back-EMF of optimized design can be employed for a regenerative braking system to charge the source [13].

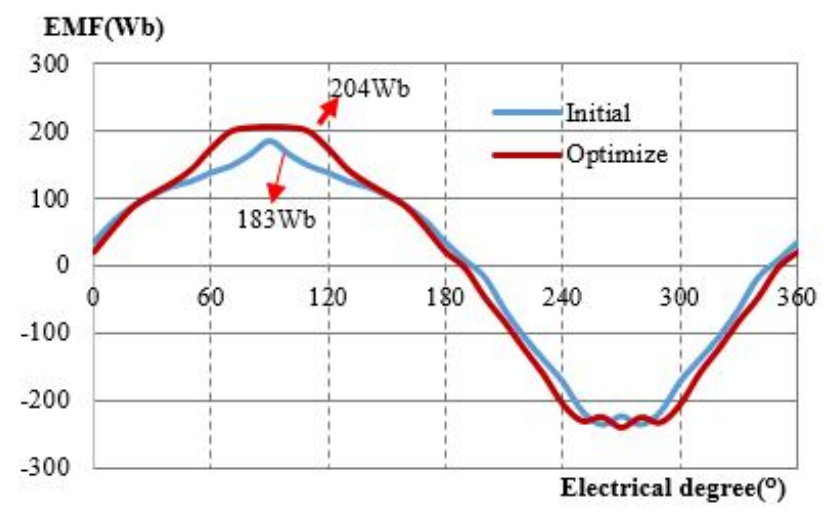

Figure 5: Back electromagnetic Force at a speed of $500 \mathrm{r} / \mathrm{min}$ 


\subsection{Performance for Analysis of Load Performance}

After all, by setting the armature current density at maximum condition, the output torque and power at various armature current density (Ja) are set to 0 to $10 \mathrm{~A}_{\mathrm{rms}} / \mathrm{mm}^{2}$ illustrated in Figure 6 and Figure 7. In the preliminary design, at the base speed of $500 \mathrm{r} / \mathrm{min}$, the performance of output torque is $4.1 \mathrm{Nm}$ whereas corresponding power is $166 \mathrm{~W}$ as seen in Figure 6. Using the application of the design optimization method (DOM), the performance of output torque at load analysis has increased significantly at $5 \mathrm{Nm}$.

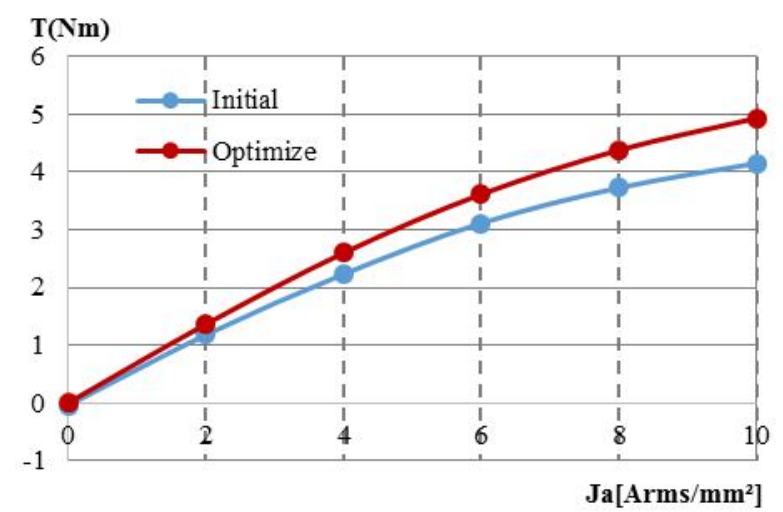

Figure 6: Analysis of Torque at various Ja

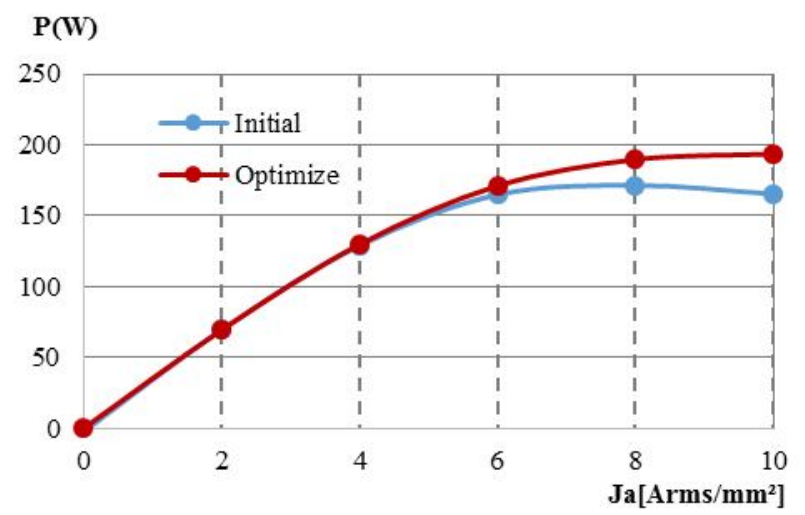

Figure 7: Analysis of Power at various Ja

The improvement of torque performance initially resulting from the enlargement in the area of armature current (AC), notably accommodates a higher number of turns and design structure of permanent magnet. Moreover, the PM weight downsizing and the optimal split ratio selection also contributing to the development of torque performance.

Accordingly, the $198 \mathrm{~W}$ of output power is generated by an optimized design compared to the initial design of $166 \mathrm{~W}$. Besides, after using the design optimization method (DOM),
$18 \%$ of the output torque is increased slightly, greater than the performance of the initial design. This condition revealed that the high value of flux linkage will develop greater torque performance. It remains, the overall effect on the proposed designs is pictured in Table 3 .

Table 3: Comparison Performance of Initial and Optimization for PMFSM Design

\begin{tabular}{|l|c|c|}
\hline Number of Slot Pole & Initial & Optimize \\
\hline Flux $(\mathrm{Wb})$ & 0.4 & 0.5 \\
\hline Cogging torque $(\mathrm{Nm})$ & 5.20 & 5.5 \\
\hline B.EMF & 183.0 & 204.0 \\
\hline Maximum torque $(\mathrm{Nm})$ & 4.1 & 5.0 \\
\hline Maximum power $(\mathrm{W})$ & 165.5 & 193.7 \\
\hline
\end{tabular}

\section{CONCLUSION}

The present discussion has demonstrated the comparison performance of initial and optimize the design of single-phase 4slot-8pole PMFSM design for electric bike applications. The comparison was made under load and no-load condition that contains few analyses. Successively, the optimized motor has greater performance compared to the initial design which reduced permanent magnet weight and better torque performance. The optimized PMFSM motor design has increased the performance of output torque to $18 \%$ whereas, at the same time, the weight of the permanent magnet is decreased by up to $20 \%$. Therefore, according to a lessening in PM weight, the motor is lightweight and potentially to reduce the cost of the motor. In the final analysis, it can be summarized with all the analytical surveys that the optimized design of PMFSM with 4slot-8pole is one of the influential design motors for electric bike applications. More important research is expected to be devoted to PMFS machines, in particular on the aspects of less PM, simple and affordable manufacturing, and further optimization.

\section{ACKNOWLEDGEMENT}

Current research studies were partly financed in part by the University of Tun Hussein Onn Malaysia under Research Fund E15501, Research Management Centre, UTHM.

\section{REFERENCES}

1. M. Baumann, B. Simon, H. Dura, and M. Weil, "The contribution of electric vehicles to the changes of airborne emissions," 2012 IEEE Int. Energy Conf. Exhib. Energycon 2012, no. 1, pp. 1049-1054, 2012.

2. G. Kahl, "Next generation screening (NGS, NGS ${ }^{\mathrm{TM}}$ )," Dict. Genomics, Transcr. Proteomics, pp. 1-1, 2015.

3. B. Marmiroli, M. Venditti, G. Dotelli, and E. Spessa, "The transport of goods in the urban environment: A comparative life cycle assessment of electric, compressed 
natural gas and diesel light-duty vehicles," Appl. Energy, 2020 .

4. M. Kendall, "Fuel cell development for New Energy Vehicles (NEVs) and clean air in China," Prog. Nat. Sci. Mater. Int., 2018.

5. J. Y. Yong, V. K. Ramachandaramurthy, K. M. Tan, and N. Mithulananthan, "A review on the state-of-the-art technologies of electric vehicle, its impacts and prospects," Renew. Sustain. Energy Rev., vol. 49, pp. 365-385, 2015.

6. L. Li, X. Li, X. Wang, J. Song, K. He, and C. Li, "Analysis of downshift's improvement to energy efficiency of an electric vehicle during regenerative braking," Appl. Energy, vol. 176, pp. 125-137, 2016.

7. X. Ding, H. Guo, R. Xiong, F. Chen, D. Zhang, and C. Gerada, "A new strategy of efficiency enhancement for traction systems in electric vehicles," Appl. Energy, vol. 205, no. 5, pp. 880-891, 2017.

8. M. B. Arias and S. Bae, "Electric vehicle charging demand forecasting model based on big data technologies," Appl. Energy, vol. 183, pp. 327-339, 2016.

9. J. Brady and M. O'Mahony, 'Development of a driving cycle to evaluate the energy economy of electric vehicles in urban areas," Appl. Energy, vol. 177, pp. 165-178, 2016.

10. N. Ba Hung, S. Jaewon, and O. Lim, "A study of the effects of input parameters on the dynamics and required power of an electric bicycle," Appl. Energy, 2017.

11. H. Chen, "The Switched Reluctance Motor Drive for Application In Electric Bicycle," pp. 1152-1156, 2001.

12. R. J. G. Citron, "Electric bicycles: Li-Ion and SLA E-Bikes: Drivetrain, Motor, and Battery Technology Trends, Competitive Landscape, and Global Market Forecasts.," Source.

13. R. Kumar, E. Sulaiman, M. Jenal, and F. S. Bahrim, "Parametric optimization and performance analysis of outer rotor permanent magnet flux switching machine for downhole application,” J. Magn, vol. 22, no. 1, pp. 69-77, Mar. 2017.

14. Z. Q. Zhu, Y. Pang, J. T. Chen., Z. P. Xia, and D. Howe, "Influence of design parameters on output torque of flux-switching permanent magnet machines," in Proc. IEEE Vehicle Power and Propulsion Conf. Sep. 2008, pp. $1-6$.

15. J. T. Chen, Z. Q. Zhu, S. Iwasaki, and R. P. Deodhar, "Influence of slot opening on optimal stator and rotor pole combination and electromagnetic performance of switched-flux PM brushless AC machines," IEEE Trans. Ind. Appl., vol.47, no.4, pp. 1681-1691, Jul./Aug. 2011.

16. Z. Q. Zhu and X. Liu, "Individual and global optimization of switched flux permanent magnet motors," in Proc. Int. Conf. Elec. Mach. Syst., Aug. 2011, pp. 1-6.

17. C. Pollock et al., "Flux-switching motors for automotive applications," IEEE Trans. Ind. Appl., vol. 42, no. 5, pp. 1177-1184, 2006.
18. F. Khan, E. Sulaiman, M. F. Omar, and M. Jenal, "Performance comparison of wound field flux switching machines," 2015 IEEE Conf. Energy Conversion, Cencon 2015, pp. 310-314, 2015.

19. F. Khan, E. Sulaiman, and M. Z. Ahmad, "Review of Switched Flux Wound-Field Machines Technology," IETE Tech. Rev. Institution Electron. Telecommun. Eng. India, vol. 34, no. 4, pp. 343-352, 2017.

20. J. T. Chen, Z. Q. Zhu, and D. Howe, "Stator and rotor pole combinations for multi-tooth flux-switching permanent-magnet brushless AC machines," IEEE Trans. Magn., vol. 44, no. 12, pp. 4659-4667, 2008.

21. M. F. Omar, E. Sulaiman, F. Khan, G. M. Romalan, and M. K. Hassan, "Performances comparison of various design slot pole of Field Excitation Flux Switching Machines with segmental rotor," 2015 IEEE Conf. Energy Conversion, Cencon 2015, pp. 320-324, 2015.

22. E. Sulaiman and T. Kosaka, "Parameter sensitivity study for optimization of field-excitation flux switching synchronous machine for hybrid electric vehicles," 2012 7th IEEE Conf. Ind. Electron. Appl., pp. 52-57, 2012.

23. R. Kumar, E. Sulaiman, M. Z. Ahmad, S. M. N. S. Othman, and F. Amin, "Comparative study of initial and optimal outer rotor permanent magnet flux switching machine for downhole application," 2017 1st Int. Conf. Latest Trends Electr. Eng. Comput. Technol. Intctelle 2017, vol. 2018-January, pp. 1-6, 2018.

24. [8]H. Pollock, C. Pollock, R. T. Walter, and B. V. Gorti, "Low Cost, High Power Density, Flux Switching Machines and Drives for Power Tools," Conf. Rec. - IAS Annu. Meet. IEEE Ind. Appl. Soc., vol. 3, pp. 1451-1457, 2003.

25. G. Zhao and W. Hua, "Comparative Study between a Novel Multi-Tooth and a V-Shaped Flux-Switching Permanent Magnet Machines," IEEE Trans. Magn., vol. 55, no. 7, pp. 1-8, 2019.

26. W. Hua, M. Cheng, Z. Q. Zhu and D. Howe. "Analysis and Optimization of Back EMF Waveform of a Flux-Switching Permanent Magnet Motor," IEEE Transactions on Energy Conversion, vol. 23, no. 3, pp. 727-733, (2008).

27. Z. Q. Zhu and D. Howe. "Influence of Design Parameters on Cogging Torque in Permanent Magnet Machines," IEEE Transactions on Energy Conversion, vol. 15, no. 4, pp. 407-412, (2000).

28. T. Shi and Z. Q. Zhu, "Analysis of Novel Multi-Tooth Variable Flux Reluctance Machines with Different Stator and Rotor Pole Combinations," in IEEE Transactions on Magnetics, vol. 51, (2015), no. 5, pp. 1-11.

29. Z. Azar, Z. Q. Zhu and G. Ombach. "Influence of Electric Loading and Magnetic Saturation on Cogging Torque, Back-EMF and Torque Ripple of PM Machines," in IEEE Transactions on Magnetics, vol. 48, no. 10, (2012), pp. 2650-2658.

30. H. Zhang, B. Kou, Y. Jin and H. Zhang, "Investigation of Auxiliary Poles Optimal Design on Reduction of End Effect Detent Force for PMLSM With Typical Slot-Pole 
Combinations," in IEEE Transactions on Magnetics, vol. 51, no. 11, pp. 1-4, Nov. 2015

31. D. Bobba, Y. Li and B. Sarlioglu, "Harmonic Analysis of Low-Stator-Slot and Rotor-Pole Combination FSPM Machine Topology for High Speed," in IEEE Transactions on Magnetics, vol. 51, no. 11, pp. 1-4, Nov. 2015

32. Z. A. Husin, E. Sulaiman and T. Kosaka, "Design studies and effect of various rotor pole number of field excitation flux switching motor for hybrid electric vehicle applications," 2014 IEEE 8th International Power Engineering and Optimization Conference (PEOCO2014), Langkawi, 2014, pp. 144-149.

33. R. Kumar, P. Kumar, R. U. Amin, B. Shankar Chowdhry and B. Das, "Optimal Rotor Pole Study of Outward Rotor Switched Flux Permanent Magnet Machine for Downhole Application," 2018 5th International Multi-Topic ICT Conference (IMTIC), Jamshoro, 2018, pp. 1-5.

34. M. Jenal, E. Sulaiman and R. Kumar, "Effects of rotor pole number in outer rotor permanent magnet flux switching machine for light weight electric vehicle, " 4th IET Clean Energy and Technology Conference (CEAT 2016), Kuala Lumpur, 2016, pp. 1-6.

35. L. I. Jusoh and E. Sulaiman, "Analysis and performance of 4S-8P permanent magnet flux switching motors (PMFSM) for electric bicycle applications," 5th IET International Conference on Clean Energy and Technology (CEAT2018), Kuala Lumpur, 2018, pp. 1-7.

36. L. I. Jusoh, a. Sulaiman and a. M. N. S. Othman, "Comparative study of single-phase FE, PM and HE flux switching motors," 2015 IEEE Student Conference on Research and Development (SCOReD), Kuala Lumpur, 2015, pp. 583-588.

37. Z. Q. Zhu, J. T. Chen, Y. Pang, D. Howe, S. Iwasaki and R. Deodhar, "Analysis of a Novel Multi-Tooth Flux-Switching PM Brushless AC Machine for High Torque Direct-Drive Applications," in IEEE Transactions on Magnetics, vol. 44, no. 11, pp. 4313-4316, Nov. 2008.

38. I. V. McLoughlin et al., "Campus Mobility for the Future: The Electric Bicycle," J. Transp. Technol., vol. 02, no. 01, pp. 1-12, 2012

39. R. Meireles, J. Silva, A. Teixeira, and B. Ribeiro, “An E . Bike Design for the Fourth Generation Bike-Sharing Services," vol. 1, pp. 1-6, 2013

40. J. Macarthur, J. Dill, and M. Person, "Electric Bikes in North America Results of an Online Survey," 2009.

41. P. H. Nguyen, E. Hoang, and M. Gabsi, "Performance Synthesis of Permanent-Magnet Synchronous Machines During the Driving Cycle of a Hybrid Electric Vehicle," IEEE Trans. Veh. Technol., vol. 60, no. 5, pp. 1991-1998, 2011.

42. S. B. Bhat, S. P. Nikam, and B. G. Fernandes, "Design and analysis of ferrite based permanent magnet motor for electric assist bicycle," Proc. - 2014 Int. Conf. Electr. Mach. ICEM 2014, pp. 106-111, 2014.

43. A. Muetze and Y. C. Tan, "Electric Bicycles- A Performance Evaluation," IEEE Ind. Appl. Mag., vol. 13, no. 4, 2007.

44. T. F. Chan, L. Yan, and S. Fang, "In-Wheel Permanent-Magnet Brushless dc Motor Drive for an Electric Bicycle," vol. 17, no. 2, pp. 229-233, 2002. 